\title{
Bioremediation Potentials of Heavy Metal Tolerant Bacteria Isolated from Petroleum Refinery Effluent
}

\author{
Enimie Endurance Oaikhena ${ }^{1}$, Dominic Bawa Makaije ${ }^{1}$, Samuel Dangmwan Denwe ${ }^{1}$, \\ Muhammad Muktar Namadi ${ }^{2}$, Ali Ahmed Haroun ${ }^{1}$ \\ ${ }^{1}$ Department of Biological Sciences, Nigerian Defence Academy, Kaduna, Nigeria \\ ${ }^{2}$ Department of Chemistry, Nigerian Defence Academy, Kaduna, Nigeria
}

Email address:

ammimuktar@yahoo.com (M. M. Namadi)

\section{To cite this article:}

Enimie Endurance Oaikhena, Dominic Bawa Makaije, Samuel Dangmwan Denwe, Muhammad Muktar Namadi, ALi Ahmed Haroun. Bioremediation Potentials of Heavy Metal Tolerant Bacteria Isolated from Petroleum Refinery Effluent. American Journal of Environmental Protection. Vol. 5, No. 2, 2016, pp. 29-34. doi: 10.11648/j.ajep.20160502.12

Received: February 8, 2016; Accepted: February 24, 2016; Published: March 30, 2016

\begin{abstract}
Five heavy metals tolerant bacteria were isolated from petroleum refinery effluent and identified as Pseudomonas aeruginosa, Staphylococcus aureus, E. coli, Proteus vulgaris and Klebsiella pneumoniae. Each isolate was inoculated into different concentrations of cadmium, chromium, nickel and zinc to determine its maximum tolerance for each heavy metal. All five isolates had low maximum tolerance concentration for cadmium $(0.9 \mathrm{mg} / \mathrm{L})$ when compared to chromium $(5 \mathrm{mg} / \mathrm{L})$, nickel $(5 \mathrm{mg} / \mathrm{L})$ and zinc $(7 \mathrm{mg} / \mathrm{L})$. Mixed culture consortium (MCC) remediated high percentage of cadmium (100\%), chromium (33.4\%), nickel (73.9\%), and zinc (90.1\%) from the petroleum refinery effluent than pure culture isolates. Among the pure culture isolates Pseudomonas aeruginosa (Cd (100\%), Cr (23.1\%), Ni (64.3\%) \& $\mathrm{Zn}(53.9 \%)$ yielded high values for the reduction of heavy metals in the refinery effluent when compared to Staphylococcus aureus, E.coli, Proteus vulgaris and Klebsiella pneumoniae. The isolated bacteria were effective for the remediation of heavy metals from petroleum refinery effluent.
\end{abstract}

Keywords: Bioremediation, Heavy Metal, Bacteria, Refinery, Petroleum

\section{Introduction}

Industrial development results in the generation of industrial effluents and if untreated, results in water, sediments and soil pollution (Fakayode, 2005). Industrial effluent is heavily loaded with different types of organic and inorganic pollutants, which are discharged into receiving water bodies (Jern, 2006).

Liquid wastes generated by refineries do compose of chemical components such as oil and grease, phenols, Benezene, Toluene, Ethyl benzene and Xylene (BTEX), ammonia, suspended solids, cyanide, sulfide, nitrogen compounds and heavy metals such as Iron $(\mathrm{Fe})$, Cadmium (Cd), Nickel (Ni), Chromium (Cr), Copper $(\mathrm{Cu})$, Molybdenum (Mo), Selenium (S), Vanadium (V) and Zinc (Zn) (Jorge et al., 2011).

Heavy metal is a general collective term that applies to the group of metals and metalloids with atomic density greater than $4000 \mathrm{kgm}-3$, or 5 times more than water (Garbarino et al., 1995). Some heavy metals are purely toxic with no known role (Shi et al., 2002) while others are essential for life at low concentration but become toxic at high concentrations (Franke et al., 2003).

Conventional physicochemical techniques for metal remediation such as filtration, acid leaching, electrochemical processes or ion exchange are expensive and may not be very effective. Biological treatment is preferred over physicochemical for toxic pollutants as the former is cost effective, efficient and environmentally friendlier (Ojo 2006; Hamza et al., 2009). Recently, studies have discovered the use of microorganisms, plants and enzymes extracted from other organisms for the remediation of pollutants in contaminated soil, water and ground water (Hamza et al., 2009; Usman et al., 2012). 
Mechanisms for metal removal by bacteria include accumulation, precipitation, complexation, volatilization, adsorption and enzyme degradation (Dubey, 2012). Bacillus spp, Pseudomonas aeruginosa, Citrobacters pp, Zoogleas pp, Chlorella vulgaris have been identified as microbes that can utilize heavy metals (Sar et al., 1999; Philip et al., 2000; Sar and D'Souza, 2001; Gunasekaran et al., 2003). The ability of microbial strains to develop in the presence of heavy metals would be helpful in wastewater treatment where microorganisms are directly involved in bioremediation of the wastewater (Munoz et al., 2006).

\section{Materials and Methods}

\subsection{Sample Collection}

Effluent samples were collected from five different discharge points of the Kaduna Refining and Petrochemical Company (KRPC) into sterilized bottles and syringes. The samples were transported to the Department of Biological Sciences Laboratory, Nigerian Defence Academy (NDA), Kaduna for bacteria isolation.

\subsection{Isolation of Possible Heavy Metals Tolerant Bacteria}

To $0.1 \mathrm{ml}$ of the 10 -fold diluted effluent samples were each inoculated using pour plate method into nutrient agar plates containing a combined concentrations of the heavy metals in their salt which include potassium dichromate $\left(\mathrm{K}_{2} \mathrm{Cr}_{2} \mathrm{O}_{7}\right)$, cadmium nitrate $\mathrm{Cd}\left(\mathrm{NO}_{3}\right)$, nickel chloride $\left(\mathrm{NiCl}_{2}\right)$ and zinc sulphate $\left(\mathrm{ZnSO}_{4}\right)$. For each nutrient plate, a concentration of $0.5 \mathrm{mg} / \mathrm{ml}$ was incorporated. The plates were incubated at room temperature for 24-48 hours. The bacteria were isolated and subcultured into nutrient plates to obtain pure cultures of each possible tolerant strain (Pandit et al., 2013).

\subsection{Test for Tolerance Trend of Bacteria Isolates to Various Concentrations of each Heavy Metal}

Each isolated bacteria was inoculated into a test tube containing $10 \mathrm{ml}$ nutrient broth at room temperature for 24 hours. Twenty microliters $(20 \mu 1)$ of the isolated bacteria were each inoculated into a nutrient broth containing different concentrations of heavy metals; $0.5 \mathrm{mg} / \mathrm{ml}, 1 \mathrm{mg} / \mathrm{ml}, 2$ $\mathrm{mg} / \mathrm{ml}, 4 \mathrm{mg} / \mathrm{ml}, 6 \mathrm{mg} / \mathrm{ml}$ and $8 \mathrm{mg} / \mathrm{ml}$ respectively for $\mathrm{Cr}$, $\mathrm{Ni}$ and $\mathrm{Zn}$ while the concentrations for Cadmium were 0.5 $\mathrm{mg} / \mathrm{ml}, 0.6 \mathrm{mg} / \mathrm{ml}, 0.7 \mathrm{mg} / \mathrm{ml}, 0.8 \mathrm{mg} / \mathrm{ml}, 0.9 \mathrm{mg} / \mathrm{ml}$ and 1 $\mathrm{mg} / \mathrm{ml}$. The inhibitory concentrations were measured using a spectrophotometer at an absorbance of $600 \mathrm{~nm}$ against a nutrient broth (blank) containing the same amount of heavy metals (Pandit et al., 2013).

\subsection{Identification of Isolated Bacteria}

Isolated colonies of the heavy metal tolerant bacteria were observed for identification based on their superficial forms (circular, filamentous and irregular); elevation (Flat, convex and umbonate), margin and shape (spiral, rod or cocci). Gram staining (Aneja, 2006) and reactions to biochemical tests were used. The results obtained were compared with bergey's manual of systematic bacteriology for the identification (Holt et al., 1994).

\subsection{Evaluation of the Potentials of Heavy Metals by Bacterial Isolates in Effluent}

The wastewater was sterilized using an autoclave at $121^{\circ}$ $\mathrm{C}$ for $15 \mathrm{mins}$. To seven $120 \mathrm{ml}$ sterile conical flasks was added $100 \mathrm{ml}$ of the sterilized wastewater each. The first flask was not inoculated with bacterium (Control), the second, third, fourth, fifth and sixth were each inoculated with $20 \mu \mathrm{l}$ of a $24 \mathrm{hrs}$ nutrient broth culture of Pseudomonas aeroginosa, Stapyloccoccus aureus, E.coli, Proteus vulgaris and Klebsiella pneumoniae respectively. The seventh flask was inoculated with a mixed culture consortium (MCC) of all the five bacteria. The experiment was left to stand for $24 \mathrm{hrs}$ after which the concentration of cadmium, chromium, nickel and zinc was measured using atomic absorption spectrophotometer. Percentage reductions of heavy metals were observed when comparism was done between the values before and after treatment.

\section{Results}

Gram staining of each colony of the heavy metal tolerant bacteria revealed isolates $\mathrm{A}, \mathrm{C}, \mathrm{D}$, and $\mathrm{E}$ as gram negative bacteria and Isolates $\mathrm{B}$ gram positive bacteria. Biochemical characterization (Table 1) of Isolates A, B, C, D and E revealed them as Pseudomonas aeruginosa, Staphylococcus aureus, E.coli, Proteus vulgaris and Klebsiella pneumoniae. The isolates showed different ranges of heavy metals tolerance using various concentration of each metal (Figure 1, 2, 3 and 4). The microbial turbidity decreased with increase in concentration of heavy metals $(0.5-8 \mathrm{mg} / \mathrm{ml})$. The Optical Density (OD) values recorded for Pseudomonas aeruginosa had Maximium Tolerance Concentration (MTC) of $0.9 \mathrm{mg} / \mathrm{L}$ for cadmium, $4 \mathrm{mg} / \mathrm{L}$ for chromium, $4 \mathrm{mg} / \mathrm{L}$ for nickel and $7 \mathrm{mg} / \mathrm{L}$ for zinc. Staphylococcus aureus had MTC of $0.8 \mathrm{mg} / \mathrm{L}$ for cadmium, $3 \mathrm{mg} / \mathrm{L}$ for chromium, $3 \mathrm{mg} / \mathrm{L}$ for nickel and $4 \mathrm{mg} / \mathrm{L}$ for zinc. Escherichia coli had MTC of $0.8 \mathrm{mg} / \mathrm{L}$ for cadmium, $5 \mathrm{mg} / \mathrm{L}$ for chromium, $3 \mathrm{mg} / \mathrm{L}$ for nickel and $6 \mathrm{mg} / \mathrm{L}$ for zinc. Proteus vulgaris had MTC of 0.6 $\mathrm{mg} / \mathrm{L}$ for cadmium, $5 \mathrm{mg} / \mathrm{L}$ for chromium, $5 \mathrm{mg} / \mathrm{L}$ for nickel and $6 \mathrm{mg} / \mathrm{L}$ for zinc. Klebsiella pneumoniae had MTC of 0.7 $\mathrm{mg} / \mathrm{L}$ for cadmium, $4 \mathrm{mg} / \mathrm{L}$ for chromium, $2 \mathrm{mg} / \mathrm{L}$ for nickel and $5 \mathrm{mg} / \mathrm{L}$ for zinc. For cadmium (Fig. 1) Pseudomonas aeruginosa had maximum tolerance while Proteus vulgaris had the minimum tolerance. Chromium (Fig. 2) was highly tolerable by E.coli and Proteus vulgaris and least by Staphylococcus aureus. Nickel (Fig. 3) had maximum tolerance by Proteus vulgaris and Pseudomonas aeruginosa and minimum tolerance by Klebsiella pneumoniae. Zinc (Fig. 4) was highly tolerable by Pseudomonas aeruginosa and least by Staphylococcus aureus.

Zinc concentration was reduced by Pseudomonas aeruginosa 53.9\%, Staphylococcus aureus 46.6\%, E.coli 
$88 \%$, Proteus vulgaris $89 \%$, Klebsiella pneumonia $20 \%$, and Mixed culture Consortium (MCC) 90.1\%. Chromium concentration was reduced by Pseudomonas aeruginosa $23.1 \%$, Staphylococcus aureus $11.6 \%$, E.coli $21.6 \%$, Proteus vulgaris 20\%, Klebsiella pneumonia 15.4\%, and Mixed Culture Consortium (MCC) 33.14\%. Nickel concentration was reduced by Pseudomonas aeruginosa 64.3\%,
Staphylococcus aureus 44.7\%, E.coli 54.4\%, Proteus vulgaris $60.47 \%$, Klebsiella pneumonia $56.3 \%$, and Mixed Culture Consortium (MCC) $73.91 \%$. Cadmium concentration was reduced by Pseudomonas aeruginosa 100\%, Staphylococcus aureus 36.1\%, E.coli 13.1\%, Proteus vulgaris 65\%, Klebsiella pneumonia $69.6 \%$ and Mixed Culture Consortium (MCC) 100\%.

Table 1. Biochemical and Morphological Characterization of the Heavy Metal Tolerant Bacteria Isolates from Petroleum Refinery Effluent.

\begin{tabular}{|c|c|c|c|c|c|}
\hline \multirow{2}{*}{$\begin{array}{l}\text { Colonial } \\
\text { Variables } \\
\end{array}$} & \multicolumn{5}{|c|}{ Cultural and Colony Morphologies } \\
\hline & IST A & IST B & IST C & IST D & IST E \\
\hline Shape & Rod & Cocci & Rod & Rod & Rod \\
\hline Colour & Green pigment & White & White & Yellow & Gray \\
\hline Form & Circular & Smooth & Circular & Circular & Irregular \\
\hline Elevation & Convex & Flat & Convex & Raised & Raised \\
\hline Gram staining & - & + & - & - & - \\
\hline Biochemical & Reactivities & & & & \\
\hline Indole & - & - & + & + & - \\
\hline Methyl red & - & + & + & + & - \\
\hline Voges Proskauer & + & - & - & + & + \\
\hline Citrate & + & + & - & - & + \\
\hline Urease & - & - & - & + & + \\
\hline Catalase & + & + & + & + & + \\
\hline Oxidase & + & + & - & - & - \\
\hline Orthinine decarboxylase & - & & - & - & - \\
\hline Mannitol & + & + & + & - & + \\
\hline Nitrate reduction & + & + & - & + & + \\
\hline $\mathrm{H}_{2} \mathrm{~S}$ production & - & - & - & + & - \\
\hline Glucose & - & & + & + & + \\
\hline Lactose & - & + & + & - & + \\
\hline Sucrose & - & & - & + & - \\
\hline Gas production & - & - & + & + & + \\
\hline Motility & + & - & + & + & + \\
\hline Probable Bacteria Isolates & P. aeruginosa & S. aureus & E. coli & P. vulgaris & K. Pneumoniae \\
\hline
\end{tabular}

Key: IST- Bacteria Isolates, + Positive, - Negative, P. aeruginosa - Pseudomonas aeruginosa, S. aureus- Staphylococcus aureus, E. coli -Escherichia coli, P. vulgaris - Proteus vulgaris and K. Pneumoniae - Klebsiella pneumoniae.

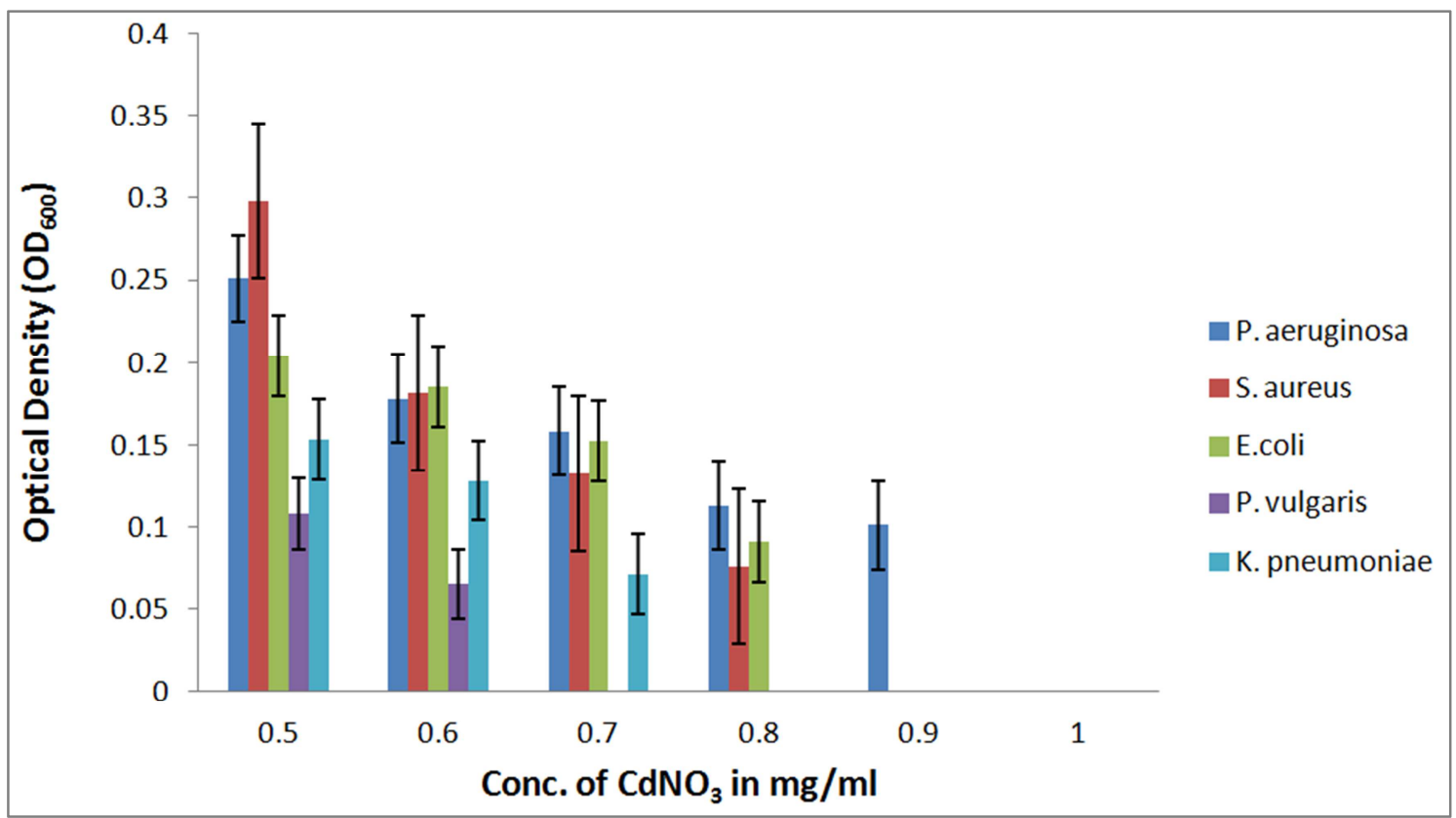

Fig. 1. Tolerance Trend of Bacteria Isolates from Refinery Effluent to Variable concentrations of CdNO $\mathrm{O}_{3}$ 


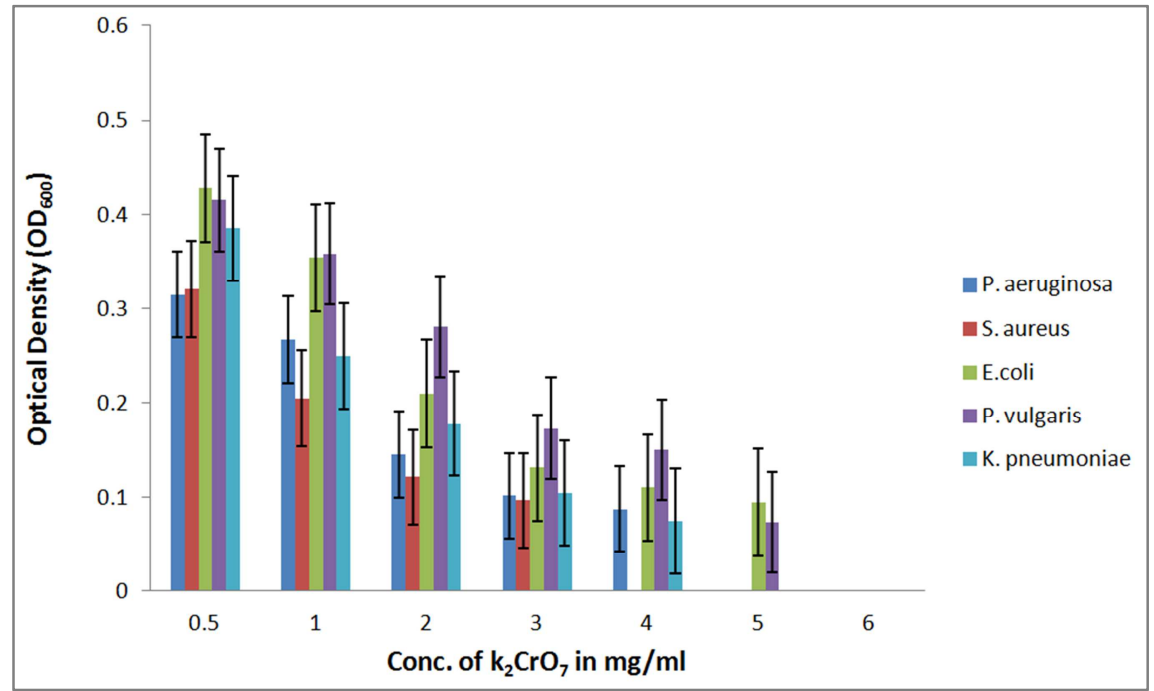

Fig. 2. Tolerance Trend of Bacteria Isolates from Refinery Effluent to Variable concentrations of $\mathrm{K}_{2} \mathrm{CrO}_{7}$.

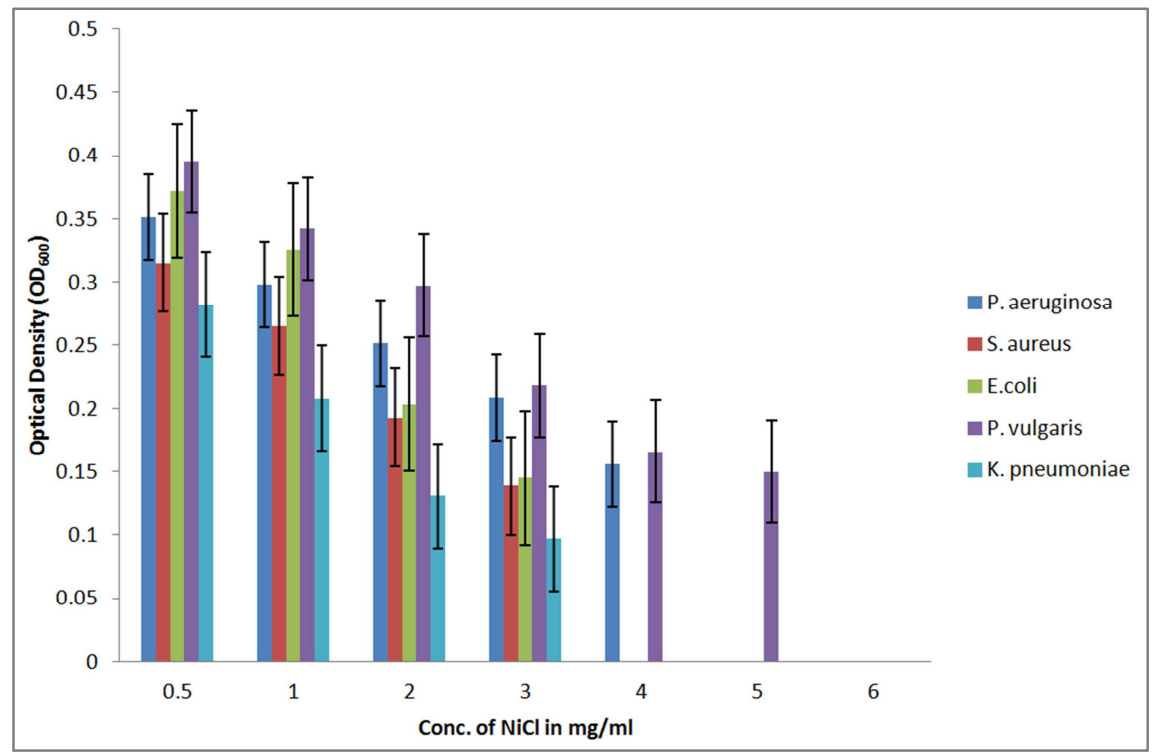

Fig. 3. Tolerance Trend of Bacteria Isolates from Refinery Effluent to Variable Concentrations of $\mathrm{NiCl}_{2}$.

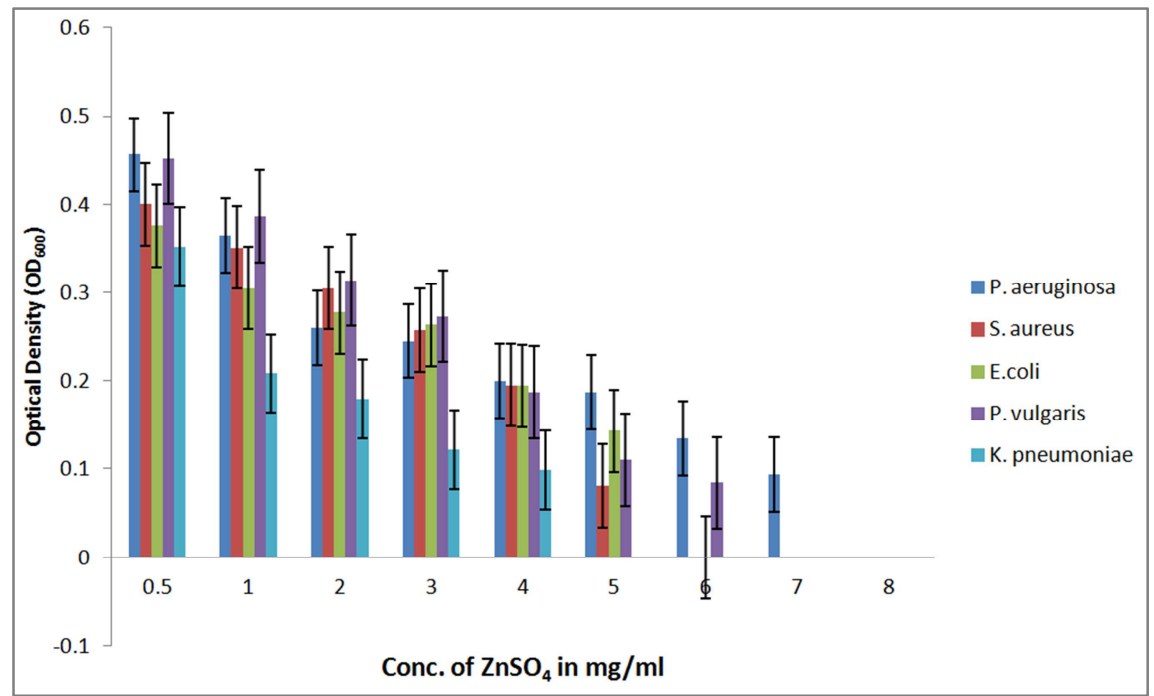

Fig. 4. Tolerance Trend of Bacteria Isolates from Refinery Effluent to Variable Concentrations of $\mathrm{ZnSO}_{4}$. 


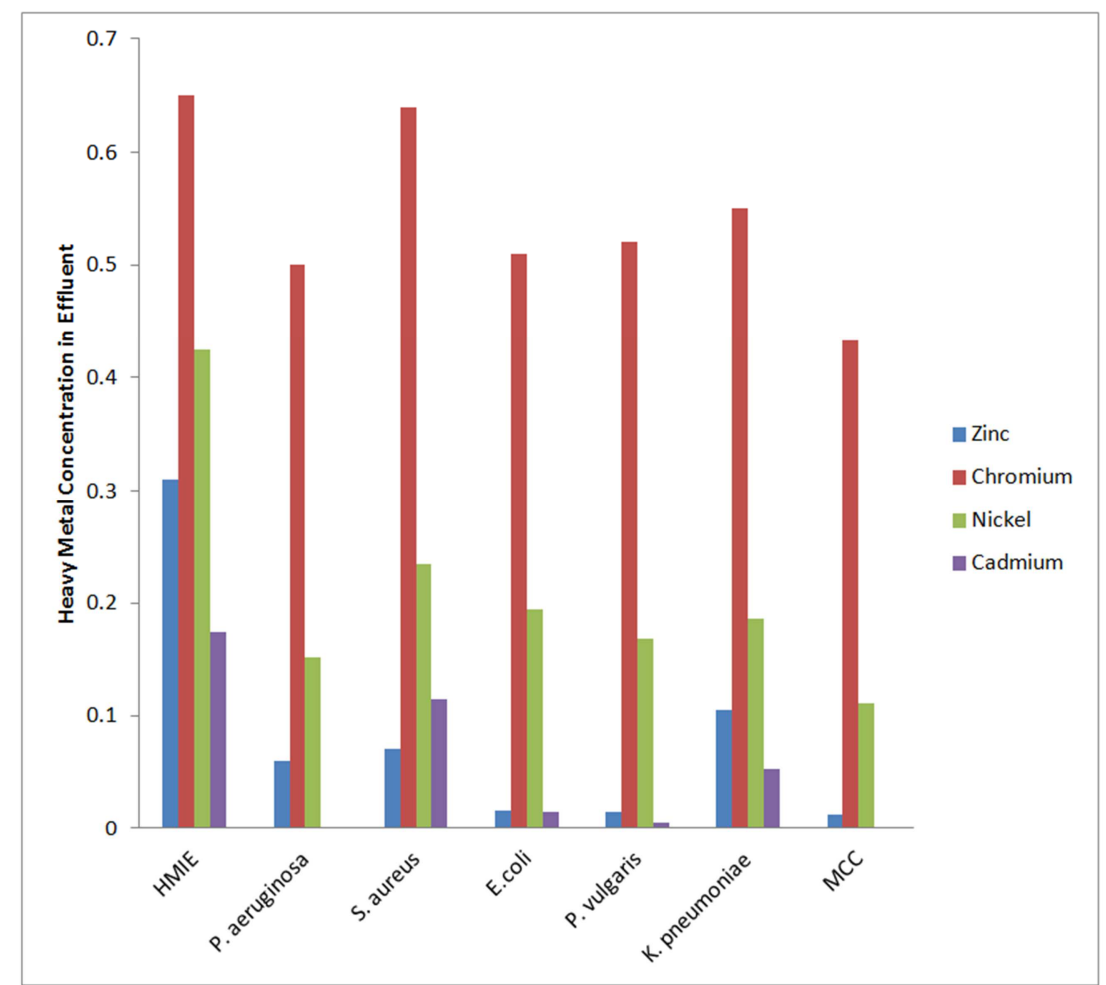

Fig. 5. Heavy Metals reduction by bacteria isolates in KRPC effluent; MCC-Mixed Culture Consortium (Consisting of all five isolates), HMIE- Heavy Metal in Effluent.

\section{Discussion}

Five bacterial isolates with maximum tolerance trend for cadmium, chromium, nickel and zinc were identified as Pseudomonas aeruginosa, Staphylococcus aureus, Escherichia coli, Proteus vulgaris and Klebsiella pneumoniae (Table 1). This work conformed to Raijbanshi (2008) who isolated Staphylococcus spp., E.coli., Klebsiella spp., Actinebacter spp., Flavobacterium spp., Citrobacter spp., Pseudomonas spp., Methylbacterium spp. as heavy metal tolerant bacteria from a sewage treatment plant in Guheswori, Nepali. Similarly, Mgbema et al. (2012) isolated Bacillus spp., E.coli, Micrococcus spp., Proteus spp., Pseudomonas spp. and Aeromonas spp. as heavy metal resistance bacteria from Otamiri River, Owerri. Among the five bacteria isolates, Pseudomonas aeruginosa showed maximum tolerance to heavy metals. This finding is in agreement with Leedjaru et al. (1996) who reported that Pseudomonas aeruginosa contains at least four Zinc or Cadmium or Lead efflux transporters and two Cadmium, Zinc and Cobalt (CZC) chemiosmotic transporters. Proteus vulgaris showed maximum tolerance to Nickel and Zinc. Proteus spp. had also been identified with high maximum tolerance to Zinc $(2.25 \mathrm{mg} / \mathrm{L})$ according to Mgbema et al. (2012).

The microbial turbidity decreased with increase in concentration of heavy metals $(0.5-8 \mathrm{mg} / \mathrm{ml})$ indicating toxic and inhibitory effect of the heavy metals on the growth of bacteria (Fig. 1, 2, 3 and 4). According to Konopka et al. (1999), the resistance mechanisms employed by the bacteria do not offer protection at extremely high levels of free metal ions and a lethal toxic effect is observed above the critical level. Metal tolerance by the five heavy metals tolerant bacteria in decreasing order was $\mathrm{Zn}>\mathrm{Ni}>\mathrm{Cr}>\mathrm{Cd}$. The higher tolerance levels for Zinc and Nickel could be attributed to their classification as micronutrients that are needed by the bacteria in trace amount (Nies, 1999). According to European Union (2004), Nickel is used in some food supplements which contain micro-grams of Nickel per tablet. Cadmium's low tolerance by the five bacteria suggests the high toxic effect of this heavy metal which has been reported to be carcinogenic and could also lead to kidney dysfunction (WHO, 2003). Low tolerance to cadmium by the five bacteria isolates in this work among other metals is similar to the report made by Smrithi and Usha (2012) who reported decreasing order of metal tolerance in their research in the sequence $\mathrm{Ni}>\mathrm{Cr}>\mathrm{Cu}>\mathrm{Zn}>$ and $\mathrm{Cd}$ for isolated heavy metal tolerant bacteria from tannery effluent in Tamil Nadu, India. But at variance from the report made by Amalesh et al. (2012) who stated that the decreasing order for metal tolerance is $\mathrm{Cd}>\mathrm{Cr}>\mathrm{Ni}>\mathrm{Co}$.

The heavy metals reduction by each bacteria isolates in the refinery wastewater revealed $P$. aeruginosa as the best heavy metal-tolerant isolate followed by $P$. vulgaris, E. coli, $K$. pneumoniae and S. aureus (Fig. 5). Pseudomonas aeruginosa showed $100 \%$ removal of Cadmium from the refinery wastewater. Momba and Ikonga (2013), in their research observed that Pseudomonas putida showed removal rates of $100 \%$ for Thalium, $96 \%$ for Lead, $83 \%$ for Vanadium, $71 \%$ for Cobalt, $57 \%$ for Nickel, $49 \%$ for Copper and $45 \%$ for Manganese. According to Vitri and Giownnetti (2008), Pseudomonas spp. has the ability to degrade heavy metals 
present in industrial effluent. In general, the Mixed Culture Consortium (MCC) of the five heavy metal-tolerant bacteria showed the highest efficacy for heavy metal reduction in the effluents. The efficacy of removal of the four heavy metals in decreasing order was MCC $>P$. aeruginos $a>P$. vulgaris $>$ E.coli $>K$. pneumoniae $>S$. aureus. The high bioremediation rate observed in MCC might be attributed to the synergy of metabolic activities by the consortium of five bacteria isolates due to the diversification of enzymatic types amongst the different types which might have enhanced the process than individual isolates with fewer enzymes types.

\section{Conclusion}

The five different bacteria isolates showed various level of maximum tolerance to different concentrations of cadmium, chromium, nickel and zinc. The efficacy of removal of the four heavy metals in decreasing order was MCC $>P$. aeruginosa $>$ P. vulgaris $>$ E.coli $>K$. pneumoniae $>S$. aureus. Overall, the mixed culture consortia had the highest percentages reduction of each heavy metal analyzed in the study. Hence, MCC are more effective for bioremediation of heavy metals than single colony bacterium.

\section{References}

[1] Aneja K R (2001). "Experiments in Microbiology". Plant pathology and Biotechnology. $4^{\text {th }}$ Edition. 102: 245-278.

[2] EU (2004). Nickel sulphate risk assessment. Prepared by the Danish Environmental Protection Agency for the European Union.

[3] Garbarino JR., Hayes H. and Roth D. (1995). Contaminants in the Mississippi River, U. S. Geological Survey Circular, Virginia, U. S. A. 1133.

[4] Gunasekaran P., Muthukrishnan J. and Rajendran P. (2003). Microbes in Heavy Metal Remediation. Indian Journal of Experimental Biology, 41: 935-944.

[5] Hamza U. D., Mohammed A. I. and Ibrahim S. (2009). Kinetics Of Biological Reduction of Chemical Oxygen Demand From Petroleum Refinery Wastewater. Researcher, Vol 1(2).

[6] Holt J. G., Krieg N. R., Sneath P. H. A., Stanley J. T and Williams S. T (1994). "Bergey's manual of determinative Bacteriology". $9^{\text {th }}$ Ed. Williams and Wilkins, pp: 71-561.
[7] Jern WNG (2006). Industrial Wastewater Treatment. Singapore: Imperial College Press.

[8] Konopka A., Zakharova T., Bischoff M., Oliver T., Nakastu. C and Turco R. F. (1990). Microbial biomass and activity in lead contaminated soil. Journal of Applied Environmental Microbiology, 65(5): 2256-2259.

[9] Mgbema I. C., Nnokwe J. C., Adjeroh L. A. and Onyemekara N. N. (2012). Resistance Of Bacteria Isolated From Otamiri River To Heavy Metals And Some Selected Antibiotics. Current Research Journal Of Biological Sciences, 4(5): 551556.

[10] Momba N. B. and Kamika I. (2013). Assessing the Resistance And Bioremediation Ability Of Selected Bacterial And Protozoan Species To Heavy Metals In Metal-Rich Industrial Wastewater. BioMedical Central Microbiology. Pp 1-14.

[11] Nies, D. H, (1999), Microbial Heavy Metal resistances. Applied Microbial biotechnology, 51: 730-750.

[12] Ojo O A (2006). "Petroleum Hydrocarbon Utilization By Native Bacterial Population From A Wastewater Canal Southwest Nigeria”. African journal of Biotechnology, 5: 333337.

[13] Philip L, Iyengar L, Venkobacher L, 2000. Site of interaction of copper on Bacillus polymyxa. Water Air Soil Pollution 119: pp 1121.

[14] Rajbanshi A. (2008). Study On Heavy Metal Resistance Bacteria In Guesswork Sewage Treatment Plant. Our Nature, 6: 52-57.

[15] Sar P, Kazy SK, Asthana RK and Singh S. P, (1999). Metal adsorption and desorption by lyophilized Pseudomonas aeruginosa. International Biodeterrioration and Biodegradation, 44: 101-110.

[16] Shi, W., Becker, J., Bischoff, M., Turco, R. F., and Konopka, A. E., (2002). Association of Microbial Community Composition And Activity With Lead, Chromium, And Hydrocarbon Contamination. Applied Environmental Microbiology, 68(8): 3859-3866.

[17] Smrithi A. and Usha K. (2012). Isolation And Characterization Of Chromium Removing Bacteria From Tannery Effluent Disposal Site. International Journal Of Advanced Biotechnology And Research, 3(3): 644-652.

[18] Usman D. H., Ibrahim A. M. and Abdullahi S. (2012). Potentials of Bacterial Isolates In Bioremediation of Petroleum Refinery Wastewater. Journal of Applied Phytotechnology in Environmental Sanitation, 1(3): 131-138. 